\title{
Combination Moringa oleiferaExtract and Ifalmin as Potential Formulation of Preventing Inflammation in Diabetic Mice Model
}

\author{
Ruri Vivian Nilamsari ${ }^{1}$, Wahyu Isnia Adharini ${ }^{1}$, Noviana Dwi Lestari ${ }^{1}$, Hideo Tsuboi ${ }^{2}$, \\ Muhaimin Rifa' $i^{1 *}$ \\ ${ }^{1}$ Department of Biology, Faculty of Mathematics and Natural Sciences, University of Brawijaya, Malang, \\ ${ }^{2}$ Department of Immunology, Nagoya University Graduate School of Medicine, Nagoya, Japan
}

Abstract

In Indonesia, the prevalence of diabetes mellitus hits 6.2\%, making Indonesia one of the top ten diabetes mellitus countries. Efforts to prevent and treat people with diabetes in Indonesia are required to minimize that as well. One is through treatment with local herbal products such as Moringa oleifera (MO) and Toman fish extract (Channa micropeltes), called Ifalmin. The aim of this research is to investigate the potential role of a combination of Extract Moringa oleifera and Ifalmin to reduce inflammation in diabetes conditions. Diabetic mice were done by Streptozotocin (STZ) induction with a single-dose $145 \mathrm{mg} . \mathrm{kg}^{-1}$.Then, diabetic mice were given an oral treatment of combination MO extract and Ifalmin for 14 days. In this experiment combinations of MO extract and Ifalmin are divide into 3 dose, There are: dose 1 ( $800 \mathrm{mg} \cdot \mathrm{kg}^{-1}: 800 \mathrm{mg} \cdot \mathrm{kg}^{-1}$ ), dose 2 ( $\left.650 \mathrm{mg} \cdot \mathrm{kg}^{-1}: 650 \mathrm{mg} \cdot \mathrm{kg}^{-1}\right)$, and dose $3\left(800 \mathrm{mg} \cdot \mathrm{kg}^{-1}: 650 \mathrm{mg} \cdot \mathrm{kg}^{-1}\right)$. Immune cells originate from the spleen are stained by immunofluorescence antibodies and analyzed by flow cytometry with BD Cellquest ProTM software. The results showed an increase of expression pro-inflammatory cytokines IL-1 $\beta$ and IL- 6 in diabetic mice compared to normal control. Only dose 1 and dose 2 has shown the capability to reduce the expression of IL-1 $\beta$ in diabetic mice. But, the combination of MO and Ifalmin has an antagonist effect on the expression of IL-6. The inhibitory mechanism can be assumed by the action of antioxidant compounds (Flavonoids and Alkaloids) in MO and Albumin compound in Ifalmin. Those combination act as exogenous antioxidant that help endogenous inside the body. A combination of $\mathrm{MO}$ extract and Ifalmin with a certain dosage was able to decrease proinflammatory cytokines IL-1 $\beta$ on the cells involved in innate immunity.

Keywords: Diabetes Mellitus, Ifalmin, Inflammation, Innate Immunity, Moringa oleifera.

\section{INTRODUCTION}

Diabetes mellitus has been a major problem in Indonesia since the 1980s, with the number of patients exceeding 10 million. Diabetes mellitus is a metabolite disorder that has spread around the world. In Indonesia, the prevalence rate of diabetics hits $6.2 \%$, making Indonesia one of the top ten countries in the world with a relatively high number of diabetics [1]. High glucose condition induced a rise in the number of lymphocytes, macrophage, and cytokine associated with inflammation such as IL-6, IL-1 $\beta$, and TNF- $\alpha$, which could adversely affect the body's physiological condition [2,3].

Diabetes also triggered imbalances in homeostasis of immune cells, Th 1 and Th 17 are upregulated, and Th 2 and $\mathrm{T}$ regulators are downregulated [4]. Th cell is a mediator to activation of $B$ cell so that they will proliferate and differentiate into plasma cells capable of producing IgG. In addition, activation of B cells will produce proinflammatory cytokines such as IL-6 [5]. Prevention and treatment efforts are

\footnotetext{
* Correspondence Address:

Muhaimin Rifa'i

E-mail : rifa123@ub.ac.id

Address :Dept. Biology, University of Brawijaya, Veteran Malang, 65145
}

needed to reduce people with diabetes in Indonesia. One of them is by treatment using local herbal such as Moringaoleifera (MO) and extract derived from Toman fish (Channamicropeltes) called Ifalmin. MO contains phytochemical compounds such as polyphenols, phenolic acids, flavonoids, alkaloids, glucosinolates, isothiocyanates, tannins, and saponins [6]. Flavonoids inside $\mathrm{MO}$, such as Quercetin, Kaempferol, Myricetin has beenreported can decrease the level of inflammation and Reactive Oxygen Species (ROS) [6].

Powder from $\mathrm{MO}$ seeds reportedly can reduce levels of IL-6 to suppress inflammation caused by high sugar levels [7]. According to Mbikay [8], MO has the potential to reduce high blood sugar in diabetic rats [9]. Ifalmin is a product derived from crude Channa micropeltes, and it is a family of Channidae that found in freshwater waters.Toman fish contain albumin, zinc, omega 6, and omega 3 [9]. The albumin content in toman fish is quite high when compared to the Channidae family of $5.35 \%$. Albumin has the potential to decrease the level of inflammation and wound healing. This research aims to investigate the potential role of a combination of Moringa oleifera extract and 
Ifalmin to reduce inflammation in diabetes conditions [10].

\section{MATERIAL AND METHOD}

\section{Animal}

The research design on this research followed the ethical clearance granted by the Universitas Brawijaya Research Ethics Committee, Indonesia No: 1180-KEP-UB. A total of 30 male Balb/c mice (Mus musculus) aged eight weeks were obtained from pathogen-free breeder Singosari, Malang. Mice were divided into six treatment groups there are healthy group, diabetic mice group, metformin group, and diabetic mice given a combination of $\mathrm{MO}$ and Ifalmin extracts with different dosage: Dose 1 (800 mg. $\mathrm{kg}^{-1}: 800 \mathrm{mg} . \mathrm{kg}^{-}$ ${ }^{1}$ ), Dose 2 (615 mg.kg-1: $615 \mathrm{mg} \cdot \mathrm{kg}^{-1}$ ), and Dose 3 (800 mg. kg $\left.{ }^{-1}: 615 \mathrm{mg} . \mathrm{kg}^{-1}\right)$. All mice are kept in a pathogen-free condition in the Animal Room, Animal Physiology Laboratory, Biology Department, Faculty of Mathematics and Natural Sciences, University of Brawijaya, Malang, Indonesia.

\section{Induction of Diabetes Mellitus}

Diabetic mice induction uses 145 mg.kg ${ }^{1}$ Streptozotocin (STZ) (Bioworld, USA). This dose is a modification from Brosius [11]. STZ was given once with intraperitoneal injection. Diabetes mice were determined when fasting glucose levels $\geq 126 \mathrm{mg} . \mathrm{dL}^{-1}$ and $\geq 200 \mathrm{mg} \cdot \mathrm{dL}^{-1}$ in without fasting.

\section{Moringa oleifera and Ifalmin Preparation}

Simplisia of Moringa oleifera (MO) leaves (Meteria Medika, Batu, East Java, Indonesia) was extracted by a modified method from Khan et al. [12]. $\mathrm{MO}$ boiled in water at $80^{\circ} \mathrm{C}$, then filtered using filter paper (Whatman No.1) freeze-dried and stored at $-20^{\circ} \mathrm{C}$. Ifalmin originated from Crude toman fish (Channa micropeltes) (PT Ismut Fitomedika Makassar, South Sulawesi, Indonesia). Two ingredients are combined based on a predetermined dosage (Dose 1 (800 mg. kg ${ }^{-1}$ : $800 \mathrm{mg} \cdot \mathrm{kg}^{-1}$ ), Dose 2 (615 mg. kg $\left.{ }^{-1}: 615 \mathrm{mg} \cdot \mathrm{kg}^{-1}\right)$, and Dose 3 (800 mg.kg-1: 615 mg.kg ${ }^{-1}$ ). Then, both materials are dissolved in Hydrobath before given to the mice diabetes mellitus group as a treatment every day for 14 days.

\section{Spleen Cell Isolation, Immunostaining, and Flow} Cytometric Analysis

After 14 days, the mice were dislocated following the last injection for spleen organ isolation. Then washed the isolated spleen using PBS and Homogenized in PBS. The homogenate was centrifuged $\left(2500 \mathrm{rpm}, 10^{\circ} \mathrm{C}, 5\right.$ minutes $)$, and for immunostaining and flow cytometry analysis, the pellet obtained was resuspended with $1 \mathrm{~mL}$ PBS. A total of $50 \mu \mathrm{L}$ resuspended splenocytes with $50 \mu \mathrm{L}$ extracellular antibodies (anti-CD11b) (BioLegend,USA) was added, then incubated at $4^{\circ} \mathrm{C}$ for 20 minutes. The sample was added after incubation with $50 \mu \mathrm{L}$ permeabilization buffer (Cytofix) (BioLegend,USA), and incubated at $4^{\circ} \mathrm{C}$ for 20 minutes.

Sample washed using $400 \mu \mathrm{L}$ wash buffer permeabilization (Washperm) (BioLegend,USA) and centrifuged $\left(2500 \mathrm{rpm}, 10^{\circ} \mathrm{C}, 5\right.$ minutes). Pellet added with $50 \mu \mathrm{L}$ intracellular antibody (BioLegend,USA), and incubated at $4{ }^{\circ} \mathrm{C}$ for 20 minutes. The sample was added with $400 \mu \mathrm{PBS}$ and transferred to a cuvette for flow cytometry analysis (BD FACS Calibur,USA).

\section{Data Analysis}

The flow cytometry results were analyzed using the BDCell Quest Pro program (BD Biosciences, USA). The data then were analyzed using one-way ANOVA and followed with the Tukey HSD test to determine the statistical difference among treatments (IBM Statistics, USA). Data were considered significant if $p<0.05$.

\section{RESULT AND DISCUSSION}

Immunomodulatory Effect on Relative Number of Proinflammatory CytokinesIL-1 $\beta$

Diabetic mice group had the highest relative number of IL-1 $\beta$ compared to other groups $(p>0,05)$. A combination extract of $\mathrm{MO}$ and Ifalmin could reduce the relative number of IL-1 $\beta$ in all dosage compared to the Diabetes group ( $p>0,05$ ) (Fig. 1).Diabetescondition causes NFkB activation, so pro-inflammatory cytokines such as IL-1 $\beta$, IL-6, and TNF- $\alpha$ could be secreted. $\mathrm{IL}-1 \beta$ is a pro-inflammatory cytokine, which plays a significant role in mediating the expression of various cytokines, adipokines, and other proinflammatory chemokines [13]. IL-1 $\beta$ can cause damage to pancreatic $\beta$ cells throughout the condition of diabetes mellitus [14].

The presence of an interleukin-1 receptor antagonist (IL-1Ra), which is one of the cytokines that inhibit the action of IL-1 $\beta$ through MyD88, can inhibit IL-1 $\beta$ signaling activity. It prevents the development of IL-1 $\beta$, so inflammation that can destroy pancreatic $\beta$ cells can be suppressed [15]. High glucose activity increased of $M 1$ but decreased of $\mathrm{M} 2$ activity[16]. Activation of $\mathrm{M} 1$ due to increased IL-6 expression, and IL-10 decreased[17]. In the case of diabetes mellitus, B-cell secreted pro-inflammatory cytokines are increased, and anti-inflammatory cytokines are decreased $[18,19]$. 
(Nilamsari, et al.)
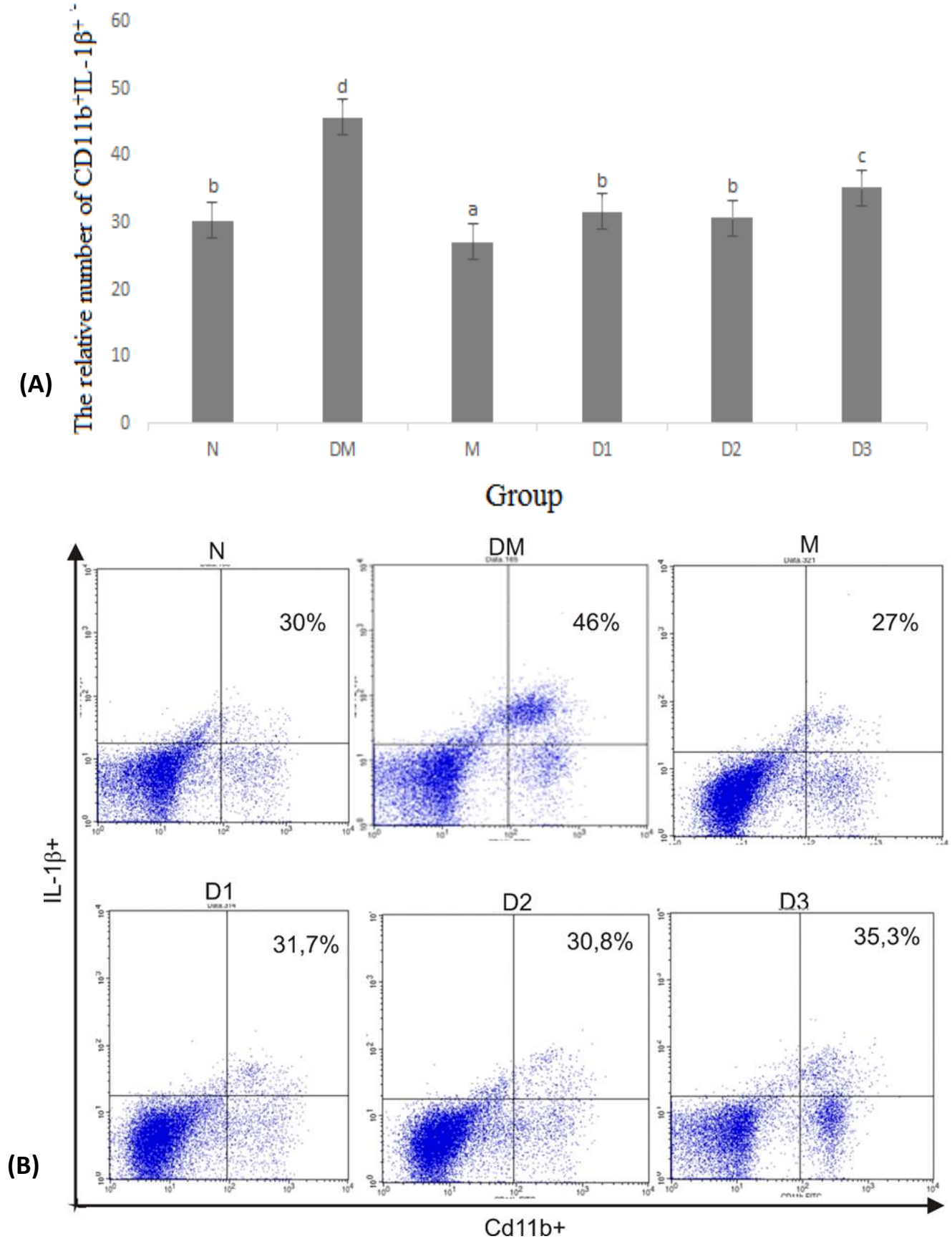

Figure 1. Effect combination extract $M O$ and Ifalmin reduce relative number IL-1 $\beta^{+}\left(C D 11 b^{+}, I L-1 \beta^{+}\right)$on statisical test (a) Effect combination extract $\mathrm{MO}$ and Ifalmin in relative number B Cell and Macrophage on diabetic mice shown in flow cytometry (b). N: Normal, DM: Diabetes Mellitus, M: Metformin, D1: Dosage 1(800 mg. $\mathrm{kg}^{-1}: 800 \mathrm{mg} \cdot \mathrm{kg}^{-}$ 1), D2: Dosage 2(615 mg.kg-1: $\left.615 \mathrm{mg} \cdot \mathrm{kg}^{-1}\right)$, D3: Dosage 3(800 mg. $\left.\mathrm{kg}^{-1}: 615 \mathrm{mg} \cdot \mathrm{kg}^{-1}\right)$. The difference in notations showed significant differences $(p<0.05)$.

Immunomodulatory Effect on Relative Number of Proinflammatory Cytokines IL-6

Meanwhile, combination of extract $\mathrm{MO}$ and Ifalmin had no significant effect to reduce relative number of IL-6 (p>0,05) between treatment group (Dose 1 (800 mg.kg-1: 800 mg.kg-1), Dose 2 (615 mg. $\mathrm{kg}^{-1}: 615 \mathrm{mg} \cdot \mathrm{kg}^{-1}$ ), and Dose 3 (800 mg. $\mathrm{kg}^{-1}$ : $615 \mathrm{mg} \cdot \mathrm{kg}^{-1}$ ) and diabetes group (Fig. 2). In diabetic rat model, Moringinine showed an increase in glucose tolerance[20]. It is documented that $\mathrm{MO}$ seed powder can also reduce IL-6 levels compared to treatment with diabetes control. This decrease in IL- 6 profile reflects a decrease in inflammatory activity due to high levels of sugar[7]. 
(Nilamsari, et al.)

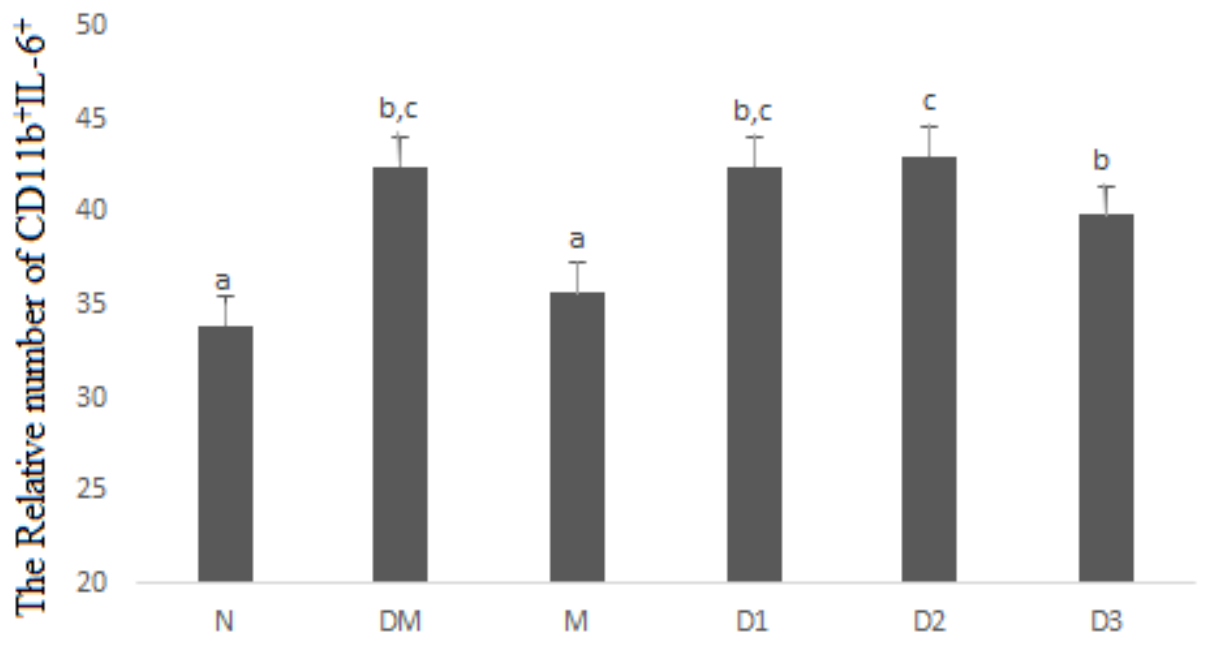

(A)

Group

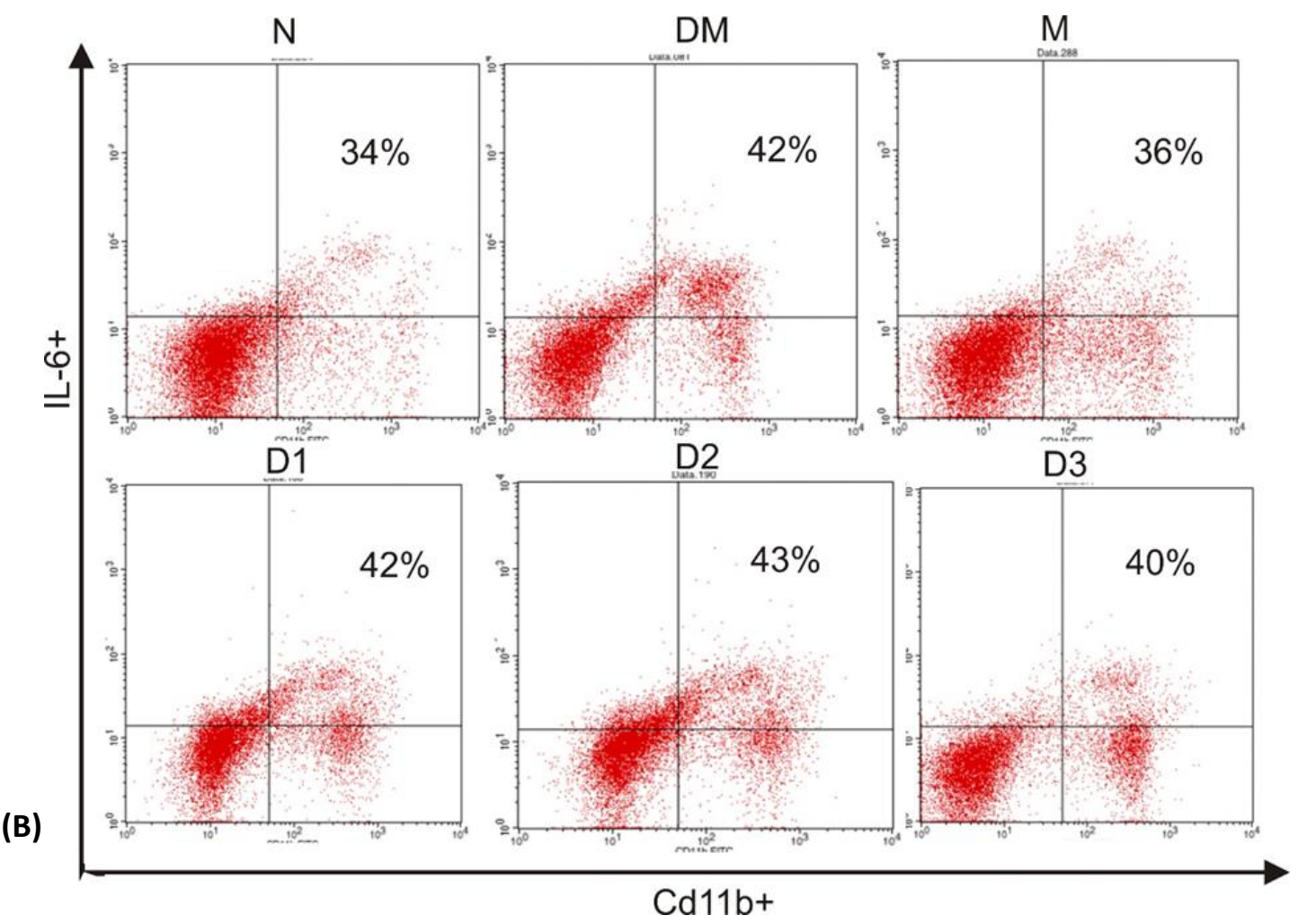

Figure 2. Combination extract $\mathrm{MO}$ and Ifalmin reduce relative number gives the opposite effect to IL-6 (CD11b+, IL-6 $6^{+}$) on statisical test (a) Effect combination extract $\mathrm{MO}$ and Ifalmin in relative number B Cell and Macrophage on diabetic mice shown in flow cytometry (b). N: Normal, DM: Diabetes Mellitus, M: Metformin, D1: Dosage 1(800 mg.kg-1: 800 mg.kg $\left.{ }^{-1}\right)$, D2: Dosage 2(615 mg.kg-1: 615 mg.kg-1), D3: Dosage 3(800 mg.kg-1: 615 mg.kg-1). The difference in notations showed significant differences $(p<0.05)$.

\section{Discussion}

In this experiment, we showed that a combination of MO extract and Ifalmin (Channa micropeltes) can deminish the production of proinflammation cytokine such as IL-1 $\beta$ and IL-6. Moringa oleifera contains of nutrients that are beneficial to humans, such as calcium, potassium, zinc, magnesium, iron, and copper [21]. Besides minerals, MO also contains several phytochemical compounds, namely polyphenols, phenolic acids, flavonoids, alkaloids, glucosinolates, isothiocyanates, tannins, and saponins [22]. There are have been reported to have sufficient amount of these antioxidants and are also used as green leafy vegetables of high total antioxidant capacity (260 mg.100 g ${ }^{-1}$ ) [22]. 
MO leaf was thought to be associated with decreased intake of intestinal glucose and slowing down of gastric emptying by fiber in $\mathrm{MO}$ leaf. It contained $12 \%$ fiber and affected postprandial plasma glucose by three major bioactive phytochemicals, including quercetin, chlorogenic acid, and moringinine [23]. Quercetin, a potent antioxidant, had antidiabetic effects in the insulin resistance model Zucker rat [24]. It has been shown that chlorogenic acid inhibits glucose6-phosphate translocase in rat liver, which has resulted in decreased hepatic gluconeogenesis and glycogenolysis[20]. In human studies, chlorogenic acid during the oral glucose tolerance test showed a decrease in the glycemic response[25].

Meanwhile, Ifalmin has been reported contain high level of Albumin. Albumin from ifalmin can act as antioxidant soit can inhibit formation of ROS [10].Albumin has the potential to reduce the number of macrophages by increasing Th 2 cells by secreting IL-10 and TGF- $\beta$ anti-inflammatory cytokines [26]. Toman fish (Channa micropeltes) also contain omega 6, which has derivatives of Arachidonic Acid (AA), which will be converted into lipoxins and have the potential to reduce the risk of inflammation due to diabetes[27].

\section{CONCLUSION}

Combination extract Moringa oleifera and Ifalmin (Crude Channa micropeltes) could decrease production of Pro-inflammatory cytokine IL-1 $\beta^{+}$in Dosage 1 (800 mg. kg ${ }^{-1}: 800$ mg.kg ${ }^{-1}$ ) and dosage 2 (615 mg. $\left.\mathrm{kg}^{-1}: 615 \mathrm{mg} . \mathrm{kg}^{-1}\right)$. But there is no significant effect on IL-6 $6^{+}$.

\section{Acknowledgment}

The authors also thank all colleagues in the Laboratory of Animal Anatomy and Physiology, Biology Department, Brawijaya University. The author also thanks Department of Biology, Faculty Mathematics and Natural Science, Brawijaya University, Indonesia for provided facilities for this research.

\section{REFERENCES}

[1] Ligita,T., W. Kristin, F. Karen, H.Nichole, N. Intansari. 2019. How people living with diabetes in Indonesia learn about their disease : A grounded theory study. Plos One.3-19.

[2] Fujioka, K. 2007.Pathophysiology of type 2 diabetes and the role of incretin hormones and beta-cell dysfunction. J. Am. Acad. Phys. 20(12). 3-8.
[3] Foulis, A.K. 2008. Pancreatic pathology in type 1 diabetes in human. Novartis Found Symp.292. 2-13.

[4] Zhou, T., H.Zheng, Y.Shou, S.Lin, Y.Zhenxiang, W.Guixia. 2018. Role of adaptive and innate immunity in type 2 diabetes mellitus. J. Diabet. Res. Article ID 7457269.1-9.

[5] Szablewski,L. 2014. Role of immune system in type 1 diabetes mellitus pathogenesis. Int. Immunopharmacol. 22. 182-191.

[6] Atkinson, M.A., S.E.George, W.M. Aaron. 2014. Type 1 diabetes. Lancet.383(9911). 69-82.

[7] Gopalakhrisnan, L., K.Doriya, D.S. Kumar. 2016. Moringa oleifera: a review on nutritive importance and its medicinal application. Food Sci. Human Wellness.5(2). 49-56.

[8] Mbikay,M. 2012. Therapeutic potential of Moringa oleifera leaves in chronic hyperglycemia and dyslipidemia: A review. Front Pharmacol.3. 24.DOI: 10.3389/fphar.2012.00024.

[9] Firlianty. 2016. Vacuum drying albumin powder of snakehead (Channa micropeltes) potential for wound healing from Central Kalimantan, Indonesia. Int. J. ChemTech Res. 9(5). 263-269.

[10] Apriasari,M.L.,A. Yusfa, F. Eka, N.C. Amy. 2018. Antioxidant effect of Channa micropeltesin diabetic wound of oral mucosa. Int. J. Pharmacol.15 (1). 137-143.

[11] Brosius, F. 2009. High-dose streptozotocin induction protocol (mouse). Diac. Comp. Consortium. 12(4). 1-3.

[12] Khan, W., P. Rabe, C. Karisma, P. Shabana, A. Sayeed. 2017. Hypoglycemic potential of aqueous extract of Moringa oleifera Leaf and In Vivo GC-MS metabolomics. Front. Pharmacol. 8(577). 1-16.

[13] Rehman, K., S.H.K. Muhammad. 2016. Mechanisms of inflammatory responses and development of insulin resistance: how are they interlinked. J. Biomed. Sci. 23. Article No. 87.

[14] Zhao, X., Q. Guangfang,W. Yiran, C. Xiao, L. Jiancan, Z.Yaping, H. Qin, W. Qijin. 2016. Elevated $\mathrm{B}$ cell activation is associated with type 2 diabetes development in obese subjects. Cell. Physiol. Biochem. 1257-1266.

[15] O'Shea,J., M. Gadina, R. M. Siegel. 2019. Cytokines and cytokine receptors. Immunity Sci. 127-153. 
[16] Khairunnida, N.C. Amy, L.A. Maharani. 2018. The effect of giant snakehead(Channa micropeltes)extract on the number of macrophage in diabetes melitus wound healing (in vivo study on the back of male wistar rat (Rattus novergicus).Jurnal Kedokteran Gigi. 3(2). 189-195.

[17] Hirayama,D., I. Tomoya, N. Hirashi. 2017. The phagocytic function of macrophageenforcing innate immunity and tissue homeostasis. Int. J. Mol. Sci. 19. 1-14.

[18] Povlou, S., L. Jamie, I. Rebecca, H. Xu, C. Mei. 2018. Sustained high glucose exposure sensitizes macrophage responses to cytokine stimuli but reduces their phagocytic activity. BMC Immunol. 19-24.

[19] Siewko,K., M. Rafal, Z.W. Anna, P.K. Anna, S. Piotr, W.K. Natalia, L. Danuta, M. Robert, G. Maria, K. Adam, S. Malgorzata. 2019. Interleukin-6 and interleukin-15 as possible biomarkers of the risk of autoimmune diabetes development. Biomed Res. Int. 1-7.

[20] Rivera, L., R. Moron, M. Sanchez, A. Zarzuelo, M. Galisteo. 2008. Quercetin ameliorates metabolic syndrome and improves theinflammatory status in obese Zucker rats.Obesity. 16(9). 2081-2087.

[21] Kasolo, J.N., S.B.Gabriel, O.Lonzy,O. Joseph,W. Jasper, O. Ogwal. 2010. Phytochemicals and uses of Moringaoleifera leaves in Ugandan rural communities. J. Med. Plant Res.4(9). 753-757.

[22] Georgewill, O.A., U.O.Georgewill, R.N.P.Nwankwoala. $2010 . \quad$ Antiinflammatory effects of Moringa oleifera lam extract in rats. Asian Pac. J. Trop. Med.3(2). 133-135.

[23] Jaiswal,D., P. Kumar, R.A. Kumar., S.M.G. Watal. 2009. Effect of Moringa oleifera Lam. leaves aqueous extract therapy on hyperglycemic rats. J. Ethnopharmacol. 123 (3). 392-396.

[24] Bennett, R.N.,F.A. Mellon, N. Foidl. 2003. Profiling glucosinolates and phenolics in vegetative and reproductive tissues of the multi-purpose trees Moringa oleifera L. (Horseradish tree) and Moringa stenopetala L. J. Agric.Food Chem.51(12). 3546-3553.

[25] Karthikesan, K.,L. Pari, V.P. Menon. 2010. Combined treatment of tetrahydrocurcumin and chlorogenic acid exerts potential antihyperglycemic effect on streptozotocinnicotinamideinduced diabetic rats.Gen. Physiol. Biophys. 29(1). 23-30.
[26] Karthikesan, K.,L. Pari, V.P. Menon. 2010. Antihyperlipidemic effect of chlorogenic acid and tetrahydrocurcumin in rats subjected to diabetogenic agents. ChemicoBiological Interactions.188(3). 643-650.

[27] Paolo,C., D.Marco, T.Alessandra, N.Lucia, S.R. Carmen, T.Manuel, B. Mauro. 2013. Clinical indications for the albumin use: Still a controversial issue. Eur. J. Intern. Med.24. 721-728. 